\title{
Effect of Sunlight on Decomposition of Soil Humic and Non-Humic Fractions
}

\author{
SOMNATH MITRA ${ }^{1}$, CHANDRIKA VARADACHARI ${ }^{2}$ and KUNAL GHOSH ${ }^{3, *}$ \\ Raman Centre for Applied and Interdisciplinary Sciences, 16A Jheel Road, Kolkata 700075, India
}

(Received on 13 May 2017; Revised on 18 August 2017; Accepted on 22 August 2017)

\begin{abstract}
Soils function as huge carbon sinks, storing more than twice the atmospheric $\mathrm{C}$. The contributions of soil organic carbon (SOC) to global warming have mainly focused on the effect of biotic factors that are accelerated by temperature rise. Recently, we demonstrated that sunlight causes significant reduction in soil organic matter (SOM). In this study, we recorded the changes in the two main fractions, humic and non-humic components of SOM under the influence of sunlight and UV light. Photodecomposition losses are higher in non-humic compared to the humic fraction. Forest soils have higher contents and proportionately larger amounts of non-humic fraction that are more rapidly decomposed. Therefore, deforestation could be a significant source of atmospheric $\mathrm{CO}_{2}$, adding about $1 \times 10^{4} \mathrm{~kg}$ of $\mathrm{CO}_{2}$ annually, for every hectare of land that is deforested. Both thermal (heat) as well as photolytic (light) effects of sunlight cause decomposition losses of humic and non-humic fractions; however, proportionately, more humic fraction is decomposed by light while non-humic fraction is more affected by heat. Increase in $\mathrm{pH}$ causes greater photodecomposition of both humic and non-humic fractions. We conclude that sunlight needs to be considered as an important causative agent for global warming, with maximum contributions from the non-humic component of SOM.
\end{abstract}

Keywords: Humic; Non-humic; Global Warming; Sunlight; Photodecomposition; Thermal Effect

\section{Introduction}

Soil organic carbon (SOC) constitutes a huge carbon sink of about $2200 \times 10^{15}$ (or $\mathrm{Pg}$ ) of $\mathrm{C}$, which is fairly labile and can add considerably to atmospheric $\mathrm{CO}_{2}$, that is around $750 \mathrm{Pg}$ of C (Batjes, 2014). It is generally accepted that the two major factors contributing to increased carbon losses from soil are microbial processes and increase in temperature. According to Bond-Lamberty and Thomson (2010), the combined effect of microbial and root respiration contributed $98 \pm 12 \mathrm{Pg} \mathrm{C}$ in 2008 . The other factor postulated to contribute significantly to carbon loss from soil to the atmosphere, is the warming effect itself (Crowther et al., 2016). According to them, the effect of warming is essentially to accelerate the biotic processes and increase fluxes to and from the soil. They estimate that global soil carbon stocks in the upper soil horizons $(0-10 \mathrm{~cm})$ will fall by $30 \pm 30 \mathrm{Pg}$ of $\mathrm{C}$ to $203 \pm 161 \mathrm{Pg}$ of $\mathrm{C}$ for each degree increase in temperature. Bellamy et al. (2005) observed that in the soils of England and Wales, carbon was lost at the rate of $0.6 \%$ per year in last 25 years; they attributed such losses to the increasing temperatures caused by global warming. Temperature effects on soil carbon decomposition have been reviewed by Davidson \& Janssens (2006), where they reiterate the general view that $\mathrm{CO}_{2}$ losses from soil organic matter (SOM) is almost entirely from respiration and microbial decomposition.

Literature on the subject, therefore, appears to emphasize biological processes as the main causative agent for carbon losses from the soil organic components. There has been very little attention to the possible role of an important abiotic factor, viz., 
sunlight on carbon depletion and its consequent implications for global carbon dioxide increases. Nevertheless, photobleaching and oxidation of dissolved organic substances have long been studied although such studies in soil systems are very limited. Chen et al. (1978) observed that photo-oxidation of dilute fulvic acid solutions exposed to UV radiation of varying wavelengths, and/or time is highly dependent on $\mathrm{pH}$. It was suggested that when exposed to sunlight, photo-production of a variety of transient oxidants, such as singlet oxygen and triplet hydroxy radicals takes place (Zeep et al., 1987) that could cause oxidation of organic substances. Long-term photochemical degradation of estuarine dissolved organic matter was studied by Moran and Zeep (2000). Therefore, although photo-chemical oxidation in solutions is well established, oxidation of carbon from soils by photo-chemical processes has not been clearly established till recently and little was known about the extent of SOC losses that could be caused simply by exposure to sunlight. In a recent study, Varadachari et al. (2017) showed that sunlight could cause 2 to $14 \%$ reduction in SOC within 3 years resulting in 5,000 to $47,000 \mathrm{~kg}$ of $\mathrm{CO}_{2}$ for every hectare of soil. Losses result from both heating effect as well as by the effect of light itself. Thus, not only temperature increases but also the sunlight itself (by photo-chemical action alone) can cause decomposition of SOC. The results are also consistent with earlier observations that forest soils in tropics are rapidly depleted in organic carbon and reach low levels within a few years of clearing and cultivation (Saikh et al., 1998).

Whereas our previous study (Varadachari et al., 2017) concerned SOC as a whole, in this paper we report how the two main fractions of SOC, viz., humic and non-humic, are photo-oxidized by the action of sunlight and UV rays. We studied 43 different soils, which were photo-oxidized under the same conditions.The data were statistically analyzed for significance of changes in humic and non-humic components. We showed how sunlight affected both humic and non-humic fractions and how both heating effect of sunlight, as well as, the photolytic action itself contributed to decomposition. The relative stability of the humic fraction and the influence of alkalinity in promoting oxidation were also studied.

\section{Materials and Methods}

Our earlier publication (Varadachari et al., 2017) provides detailed information on the soil samples used here. Briefly, this included three soils of characteristically different agro-climatic zones and mineralogy, as well as, 40 soils from within the Simlipal National Park (Saikh et al., 1998). The latter provided an interesting scenario, where cultivated lands and the corresponding adjoining forest lands occur in close proximity in topographically similar locations. Apart from the cultivated lands, sampling sites comprised a variety of vegetative zones including evergreen forests, deciduous forests and natural grasslands.

Experimental details were as described earlier (Varadachari et al., 2017). Soil samples (1 g of each) were placed in glass tubes with the open end covered with a film of permeable plastic. Another set of samples was taken in glass tubes coated with black paint. All tubes were laid out horizontally in trays and placed in sunlight every day for up to three years ( 8 h/day x 6 days x 45 weeks x 3 years) (excluding 7 weeks of rainy season). Samples in test tubes with black coating experienced only heating effect of sunlight, whereas in test tubes without the coating, the samples were subjected to both effects of the light rays (from sunlight) as well as heat.

For simulation experiments with UV light, $10 \mathrm{~g}$ of each soil sample was spread in a petridish and irradiated by UV-B source [Philips HPL-N, $125 \mathrm{~W}$, high pressure mercury lamp of light intensity $4.75 \times 103$ $\mathrm{Lm}$.] for up to a period of $250 \mathrm{~h}$. Soils were also treated with dilute $\mathrm{NaOH}$ or $\mathrm{HCl}$ to adjust $\mathrm{pH}$ to desired levels, dried and sieved through $2 \mathrm{~mm}$. These soils were also subjected to UV exposure. Triplicate samples were studied for all experiments.

SOC was determined by dichromate oxidation using the modified Walkley-Black method (Nelson and Sommers, 1996) and reported in the previous work (Varadachari et al., 2017). Humic fraction was extracted from the soils following the standard procedure. Soils (1 g each),prewashed with $0.1 \mathrm{~N}$ $\mathrm{H}_{2} \mathrm{SO}_{4}$, was shaken with $0.1 \mathrm{~N} \mathrm{NaOH}(10 \mathrm{~mL})$ for an hour, left overnight and the humic extract was adjusted to $\mathrm{pH}$ 8.05; then $40 \mathrm{~mL} 0.5 \mathrm{M} \mathrm{NaHCO}_{3}$ was added and the volume made up to $100 \mathrm{~mL}$. Concentration of humic fraction was measured by a UV-Visible spectrophotometer at $465 \mathrm{~nm}$. Standard curve of each humic fraction was prepared by extracting the humic fraction from each soil, dissolving a weighed amount in $0.1 \mathrm{~N} \mathrm{NaOH}$, adjusting to $\mathrm{pH} 8.05$ and preparing a 
standard curve with the stock solution of HA with the same amount of $\mathrm{NaHCO}_{3}$ as in the extracts. Amount of non-humic fraction in the soils was estimated by the difference between total SOC and humic fraction in the soils. All analyses were repeated thrice and the average value was recorded. Statistical significance of the changes in humic and non-humic fractions was estimated by paired $t$ test.

\section{Results and Discussion}

\section{Oxidation of Humic and Non-humic Fractions by Sunlight}

Table 1 shows the humic and non-humic contents in the soils under different vegetative cover from Simlipal National Park. Humic fraction amounts to about 5$14 \%$ of the total SOM in the soils. It appears that, in general, soils under cultivation have a larger humic fraction in SOM whereas, the forest soils are proportionately richer in non-humic organics. Losses in humic fraction in 3 years range from 0.1 to $0.9 \mathrm{~g}$ $\mathrm{kg}^{-1}$ of soil (Fig. 1); changes in humic contents are all significant at 5\% level. In general, cultivated soils show greater losses of humic fraction compared to their adjoining forest lands. One explanation for greater losses from cultivated lands could be that the humic fractions have previously been exposed to sunlight and thereby suffered some degree of photo- degradation to smaller and more susceptible molecules (Varadachari et al., 2017).

As expected, loss in humic fraction increases from the second to the third year, but such increased losses are more pronounced for forest soils (11E, 12E, 29E, 21D, 24D, 11G, 12G). The observation that there is a large increase in humic fraction degradation from the $2^{\text {nd }}$ year to the $3^{\text {rd }}$ year in forest soils further strengthens the hypothesis that smaller molecules of the humic fraction are produced by exposure to sunlight that degrade more rapidly in the subsequent years.

Photo-degradation trends with non-humic fractions of soils show that the amounts of non-humic fraction lost from soils are much higher than losses in the humic fraction. This suggests that the non-humic fractions of soils are much more susceptible to photodegradation by sunlight as compared to the humic fraction. Moreover, the amounts of non-humic fraction oxidized from cultivated soils are much less than the adjoining forest lands. Differences between losses of humic and non-humic fraction increase from the $2^{\text {nd }}$ to the $3^{\text {rd }}$ year (Fig. 2A \& 2B). In the $3^{\text {rd }}$ year, amount of non-humic fraction oxidized ranges from 2-10 $\mathrm{g}$ $\mathrm{kg}^{-1}$ of soil, whereas humic fraction oxidized is less than $0.7 \mathrm{~g} \mathrm{~kg}^{-1}$ (Fig. 2B). Considering that all cultivated soils have significantly less non-humic organic matter compared to the adjoining forest lands (Table 1), it

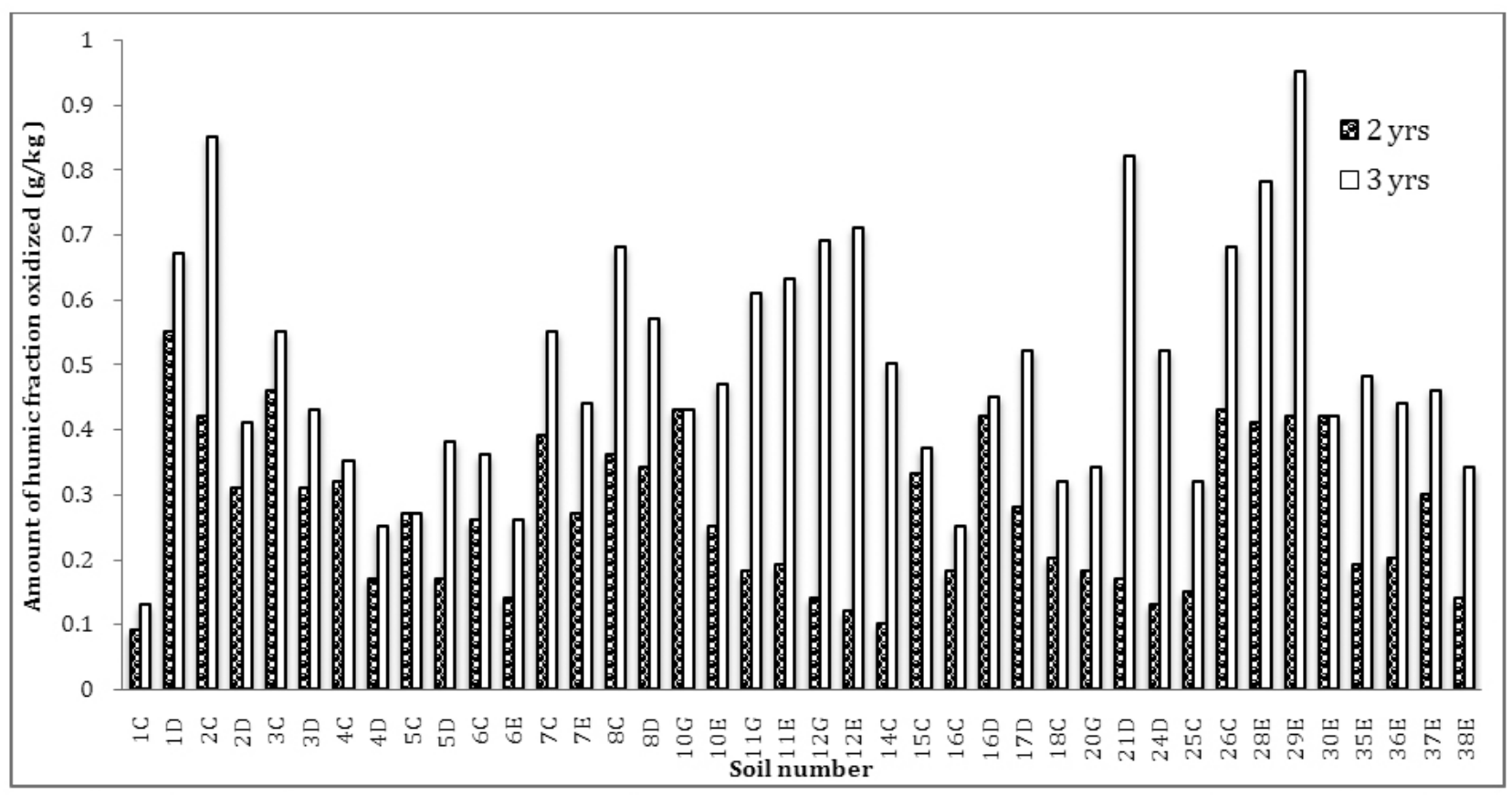

Fig. 1: Amount of humic fraction oxidized from soils after 2 and 3 years exposure to sunlight 
Table 1: Humic and non-humic contents in soils

\begin{tabular}{|c|c|c|c|c|}
\hline Soil $\mathrm{No}^{\mathrm{b}}$ & $\begin{array}{l}\text { Initial } \\
\text { SOM } \\
\left(\mathrm{g} \mathrm{kg}^{-1}\right)^{\mathrm{a}}\end{array}$ & $\begin{array}{l}\text { Initial } \\
\text { humic } \\
\text { fraction } \\
\left(\mathrm{g} \mathrm{kg}^{-1}\right)\end{array}$ & $\begin{array}{l}\text { Initial } \\
\text { non-humic } \\
\text { fraction } \\
\left(\mathrm{g} \mathrm{kg}^{-1}\right)\end{array}$ & $\begin{array}{c}\text { Humic } \\
\text { fraction } \\
(\% \text { of SOM })\end{array}$ \\
\hline $1 C^{R}$ & 15.0 & 1.03 & 14.0 & 6.87 \\
\hline $1 \mathrm{D}$ & 84.5 & 5.87 & 78.6 & 6.95 \\
\hline $2 C^{R}$ & 17.8 & 9.06 & 8.7 & 51.02 \\
\hline $2 \mathrm{D}$ & 52.9 & 3.73 & 49.2 & 7.05 \\
\hline $3 \mathrm{C}^{\mathrm{O}}$ & 30.0 & 3.08 & 26.9 & 10.27 \\
\hline $3 \mathrm{D}$ & 58.4 & 4.10 & 54.3 & 7.02 \\
\hline $4 C^{\mathrm{M}}$ & 26.5 & 3.52 & 23.0 & 13.26 \\
\hline $4 \mathrm{D}$ & 36.2 & 2.23 & 34.0 & 6.16 \\
\hline $5 \mathrm{C}^{\mathrm{M}}$ & 33.3 & 2.80 & 30.5 & 8.42 \\
\hline $5 \mathrm{D}$ & 52.1 & 5.20 & 46.9 & 9.99 \\
\hline $6 \mathrm{C}^{\mathrm{O}}$ & 23.3 & 1.52 & 21.8 & 6.53 \\
\hline $6 \mathrm{E}$ & 107.6 & 6.26 & 101.3 & 5.82 \\
\hline $7 C^{R}$ & 45.2 & 4.75 & 40.4 & 10.52 \\
\hline $7 \mathrm{E}$ & 101.0 & 7.65 & 93.4 & 7.57 \\
\hline $8 C^{R}$ & 36.2 & 2.00 & 34.2 & 5.52 \\
\hline $8 \mathrm{D}$ & 58.3 & 4.73 & 53.5 & 8.12 \\
\hline $10 \mathrm{G}$ & 40.9 & 3.00 & 37.9 & 7.34 \\
\hline $10 \mathrm{E}$ & 111.5 & 4.25 & 107.3 & 3.81 \\
\hline $11 \mathrm{G}$ & 45.2 & 4.20 & 41.0 & 9.30 \\
\hline $11 \mathrm{E}$ & 60.2 & 6.05 & 54.1 & 10.06 \\
\hline $12 \mathrm{G}$ & 58.8 & 2.15 & 56.6 & 3.66 \\
\hline $12 \mathrm{E}$ & 100.5 & 6.13 & 94.4 & 6.10 \\
\hline $14 \mathrm{C}^{\mathrm{O}}$ & 11.2 & 1.06 & 10.1 & 9.46 \\
\hline $15 C^{R}$ & 26.5 & 2.54 & 24.0 & 9.57 \\
\hline $16 C^{R}$ & 13.4 & 1.00 & 12.4 & 7.44 \\
\hline $16 \mathrm{D}$ & 26.7 & 3.66 & 23.1 & 13.70 \\
\hline $17 \mathrm{D}$ & 74.3 & 5.64 & 68.7 & 7.59 \\
\hline $18 C^{R}$ & 16.4 & 1.32 & 15.1 & 8.06 \\
\hline $20 \mathrm{G}$ & 33.1 & 3.36 & 29.7 & 10.15 \\
\hline $21 \mathrm{D}$ & 60.0 & 5.35 & 54.6 & 8.92 \\
\hline $24 \mathrm{D}$ & 51.4 & 5.23 & 46.1 & 10.18 \\
\hline $25 \mathrm{C}^{\mathrm{O}}$ & 29.7 & 2.15 & 27.5 & 7.25 \\
\hline $26 \mathrm{C}^{\mathrm{O}}$ & 20.9 & 3.00 & 17.9 & 14.38 \\
\hline $28 \mathrm{E}$ & 122.9 & 7.58 & 115.3 & 6.17 \\
\hline $29 \mathrm{E}$ & 101.7 & 7.95 & 93.8 & 7.82 \\
\hline $30 \mathrm{E}$ & 92.2 & 6.54 & 85.7 & 7.09 \\
\hline $35 \mathrm{E}$ & 107.6 & 6.11 & 101.5 & 5.68 \\
\hline $36 \mathrm{E}$ & 90.5 & 6.12 & 84.4 & 6.76 \\
\hline $37 \mathrm{E}$ & 105.9 & 4.56 & 101.3 & 4.31 \\
\hline $38 \mathrm{E}$ & 72.9 & 4.26 & 68.7 & 5.84 \\
\hline
\end{tabular}

a. Data taken from Varadachari et al. (2017) for SOC and converted to SOM using factor 1.724; b. Similar numbers are paired soils. Suffixes C, D, G, E refer to cultivated, deciduous, grassland and evergreen forest lands. Superscript refers to length of periods under cultivation viz., $\mathrm{O}$ : old cultivations (> $60 \mathrm{yrs}$ ), $\mathrm{M}$ : medium period cultivations $(20-60 \mathrm{yrs})$ and $\mathrm{R}:$ recent cultivations $(<20$ yrs) may be further inferred that when forest lands are cleared for cultivation, sunlight rapidly degrades the non-humic SOM by photo-chemical processes. Proportionately, there is an increase in the humic fraction, since it degrades at a much slower rate. Therefore, deforestation could be a significant source of atmospheric $\mathrm{CO}_{2}$ adding about $1 \times 10^{4} \mathrm{~kg}$ of $\mathrm{CO}_{2}$ annually for every hectare of land that is deforested.

A plot of amount of humic fraction oxidized versus the initial humic fraction in soil (Fig. 3) shows an overall trend of higher losses with increase in the content of humic fraction. The data, however, show a great deal of scatter and the correlation is not significant. This suggests that factors of the soil itself such as soil mineralogy, etc., do have a significant influence on the photo-decomposition process.

\section{Influence of Heat Versus Light}

In our earlier work (Varadachari et al., 2017), we observed that SOC decomposition from soils occurred both under the influence of heat effect of sunlight as well as photochemical effect itself. Decomposition due to 'heat effect' of sunlight and 'light effect', was obtained by comparing losses in humic fraction in soils kept in darkened tubes (heat effect only) with losses in HA in samples kept in clear glass tubes (heat + light effect) for upto 3 years. Relative amounts of humic fraction losses due to heating and light effects after 3 years exposure to sunlight are shown in Fig. 4A; corresponding losses in the non-humic fraction are shown in Fig. 4B. Proportionately, more humic fraction is lost due to light effect (photolytic decomposition) than due to heat effect (thermal decomposition) in a majority of the soils. Degradation of humic acid in solution by UV irradiation was observed to produce low molecular weight organic acids (Allard et al., 1994). Although the soil matrix itself should have protective shield against penetration by UV rays, significant humic fraction was nevertheless decomposed. The non-humic fraction showed proportionately greater losses by thermal effects rather than by light (Fig. 4B).

This feature is also observed in three different soils of varying characteristics (Table 2). Whereas humic fraction losses due to thermal and photolytic effects were nearly similar, with non-humic fraction, much larger amounts were degraded by thermal effects than by light. Since a considerable fraction of 


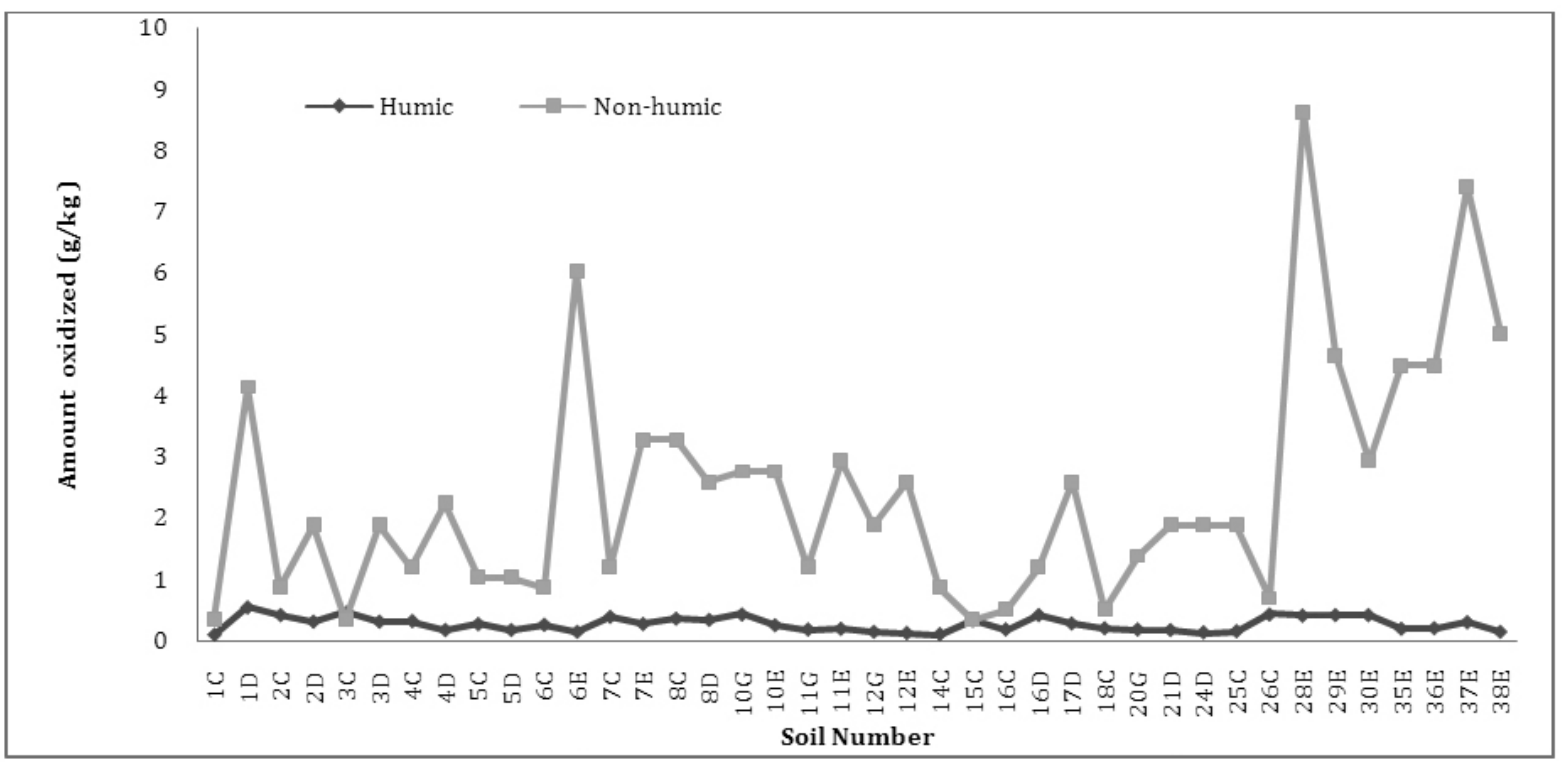

Fig. 2 : Photochemical losses of humic and non-humic fractions from soils after (a) 2 years (b) 3 years

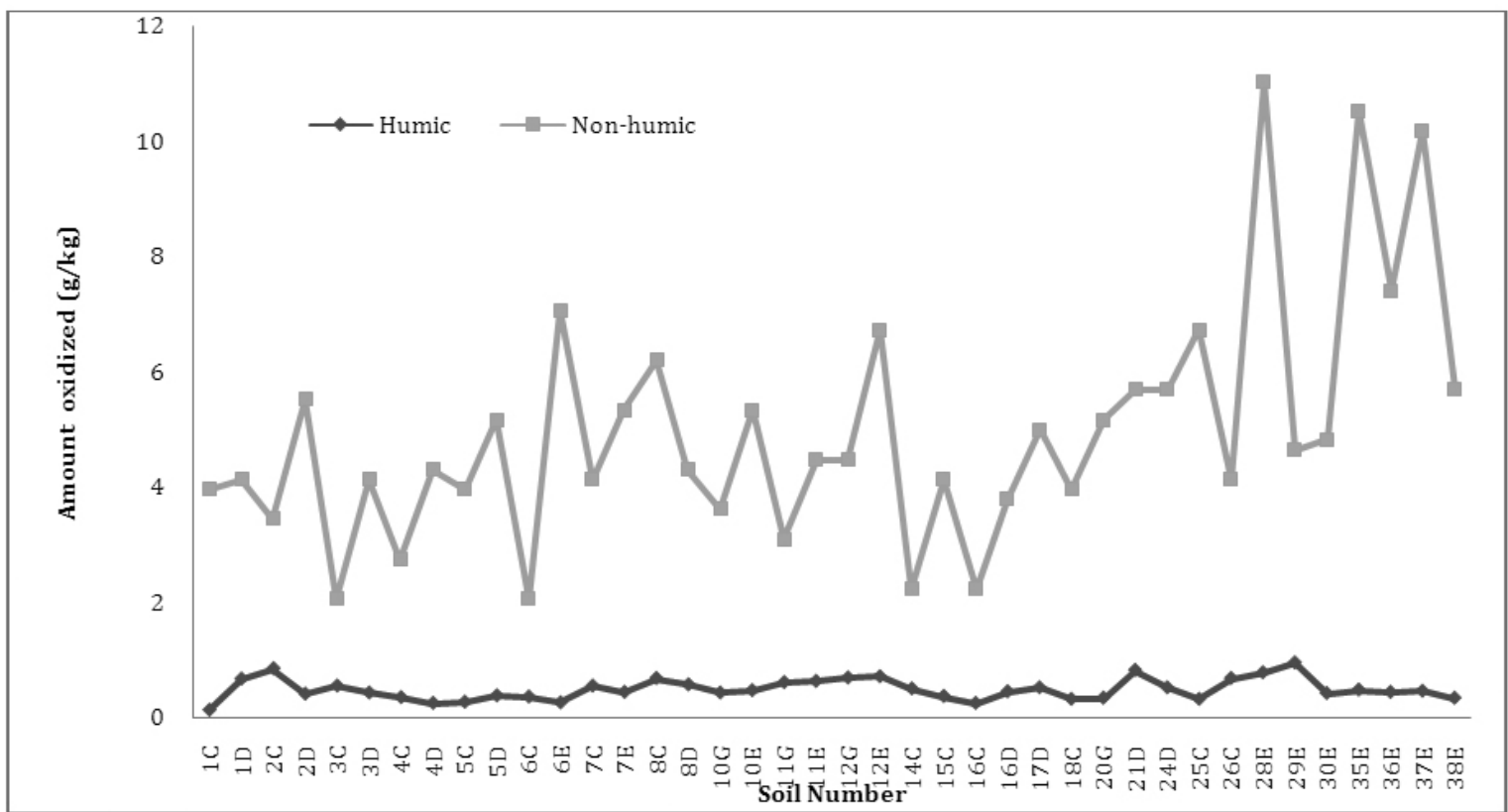

Fig. 3: Correlation between initial amounts and losses of humic fraction due to photodecomposition after 3 years

Table 2: Photo-decomposition of humic and non-humic fractions

\begin{tabular}{|c|c|c|c|c|c|c|c|c|c|c|}
\hline \multirow[t]{2}{*}{ Soil } & \multirow{2}{*}{$\begin{array}{l}\text { Initial } \\
\text { humic } \\
\text { fraction }\end{array}$} & \multirow{2}{*}{$\begin{array}{c}\text { Initial } \\
\text { non-humic } \\
\text { fraction }\end{array}$} & \multirow{2}{*}{$\begin{array}{c}\text { Humic } \\
\text { fraction } \\
\text { (\% of } \\
\text { SOM) }\end{array}$} & \multirow{2}{*}{$\begin{array}{c}\text { Humic } \\
\text { fraction } \\
\text { after } \\
3 \text { years }\end{array}$} & \multicolumn{3}{|c|}{$\begin{array}{l}\text { Humic fraction losses } \\
\text { after } 3 \text { years }\left(\mathrm{g} \mathrm{kg}^{-1} \text { soil }\right)\end{array}$} & \multicolumn{3}{|c|}{$\begin{array}{l}\text { Non-humic fraction losses } \\
\text { after } 3 \text { years }\left(\mathrm{g} \mathrm{kg}^{-1} \text { soil }\right)\end{array}$} \\
\hline & & & & & $\begin{array}{l}\text { Total } \\
\text { loss }\end{array}$ & $\begin{array}{l}\text { Loss due to } \\
\text { light effect* }\end{array}$ & $\begin{array}{l}\text { Loss due to } \\
\text { heat effect* }\end{array}$ & $\begin{array}{l}\text { Total } \\
\text { loss }\end{array}$ & $\begin{array}{c}\text { Loss due } \\
\text { light effect* }\end{array}$ & $\begin{array}{c}\text { Loss due } \\
\text { heat effect* }\end{array}$ \\
\hline Entisol & 2.78 & 14.00 & 9.60 & 2.62 & 0.16 & 0.08 & 0.08 & 1.50 & 0.75 & 0.75 \\
\hline Alfisol & 1.00 & 8.20 & 6.32 & 0.83 & 0.17 & 0.09 & 0.08 & 0.86 & 0.39 & 0.47 \\
\hline Mollisol & 7.36 & 80.40 & 4.87 & 7.20 & 0.16 & 0.07 & 0.09 & 2.25 & 0.34 & 1.91 \\
\hline
\end{tabular}

* Data significant at $\mathrm{P}=5 \%$ 


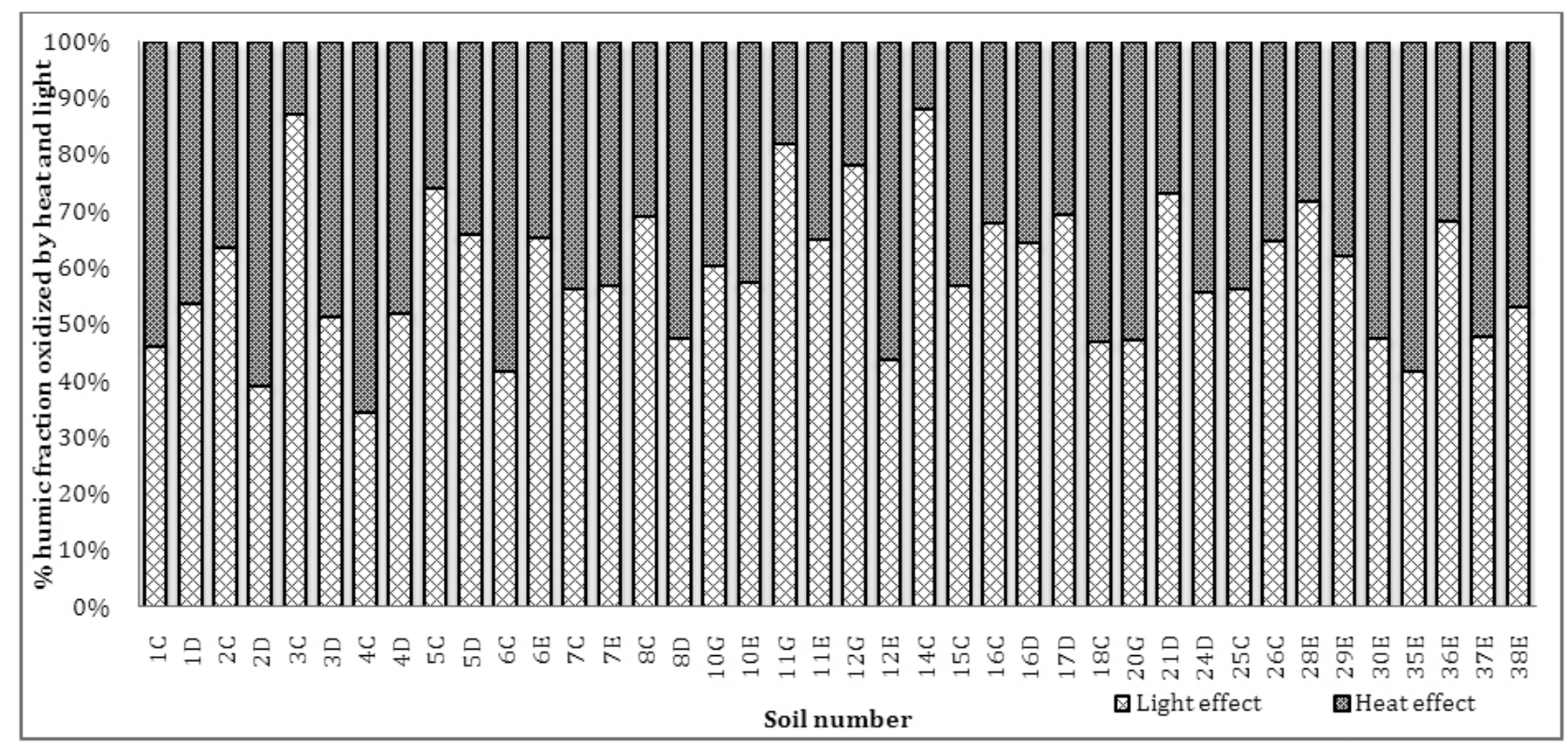

(A)

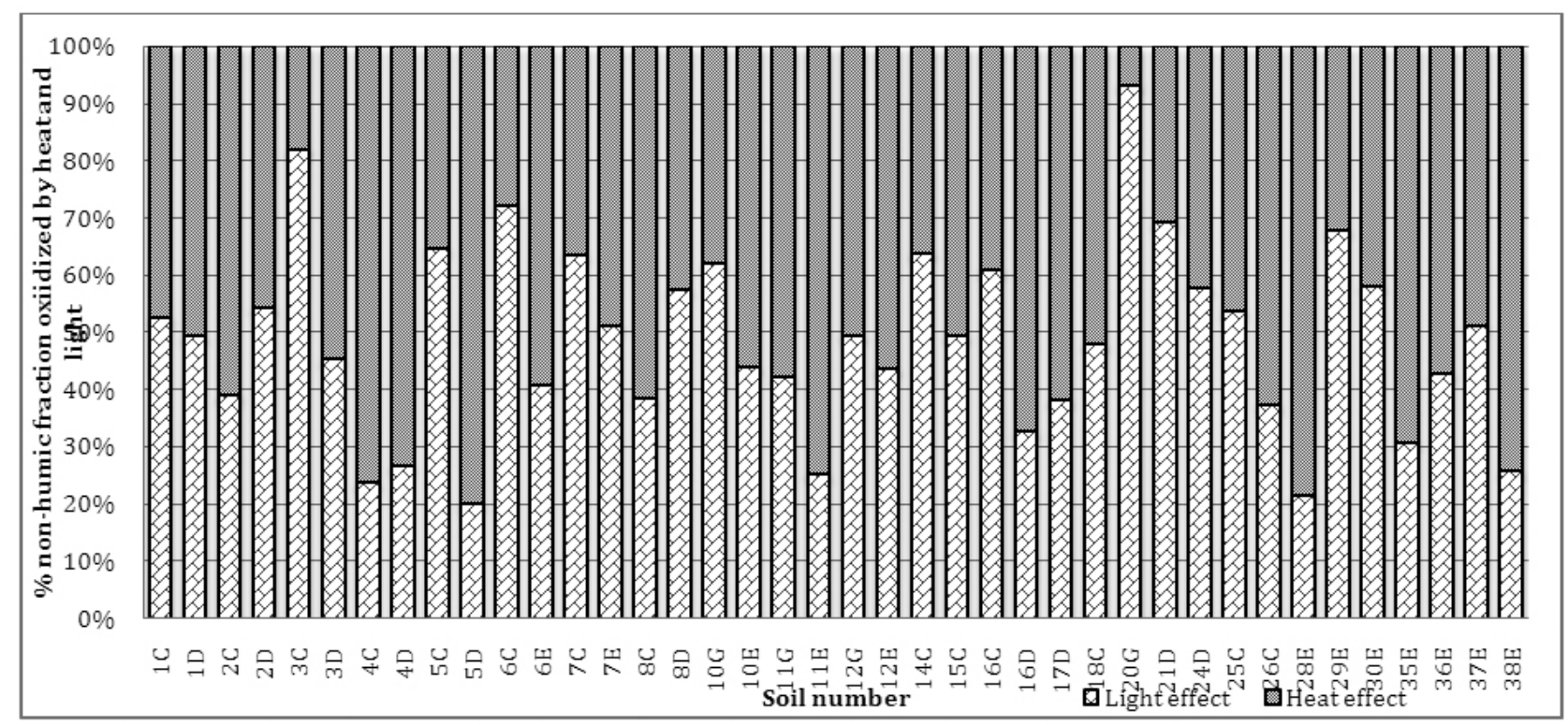

(B)

Fig. 4: (A) Proportion of humic fraction and (B) Proportion of non-humic fraction oxidized due to effect of heat and effect of light after 3 years exposure to sunlight

SOM may be present in the non-humic fraction, the influence of thermal effects of sunlight is expected to contribute significantly to atmospheric $\mathrm{CO}_{2}$. The general view amongst researchers (Crowther, 2016; Davidson and Janssens, 2006) is that thermal effects of SOM losses from soils are due the acceleration of biological processes. The results we obtained suggest that apart from biological factors, purely abiotic thermal effects of sunlight are also significantly important contributory factors of SOM losses (in addition to photolytic effects).

\section{Influence of $\mathrm{pH}$ on Photo-decomposition by $\mathrm{UV}$}

Photo-decomposition of SOM fractions from three different soils exposed to UV light is shown in Fig. 5. As observed with sunlight decomposition, UV light also caused greater loss of non-humic fraction compared to the humic fraction. In terms of percentage reduction, Entisol had the highest humic fraction loss of $42 \%$, while highest percentage non-humic fraction 


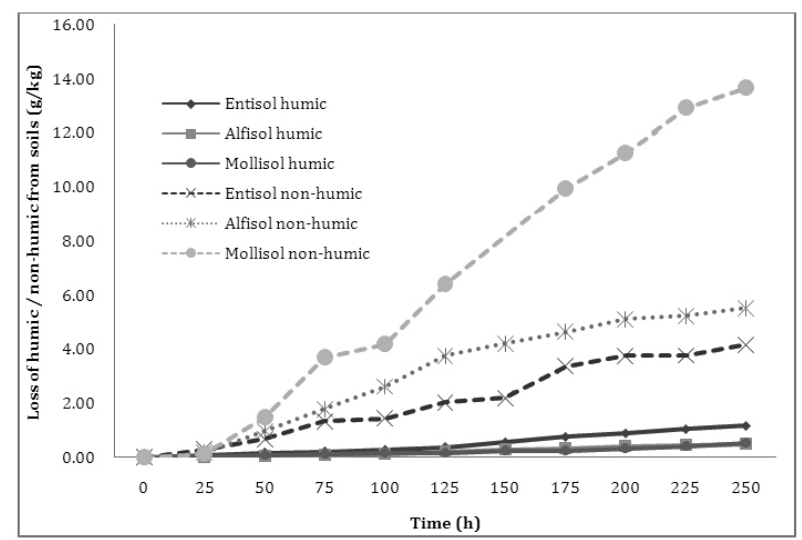

Fig. 5: Losses in humic and non-humic fractions from soil by UV irradiation

loss was from the Alfisol (37\%). Although Mollisol lost the largest amounts of both humic and non-humic fractions, the percentage losses were the least (7 and 9.5\% respectively). Significantly higher oxidation of non-humic fractions over the humic fraction may be attributed to stabilizing effect of the macromolecular structure of humic substances. Differences in oxidation between the soils have been attributed to bonding with clay minerals (Varadachari et al., 2017). Protecting effect of clays would be higher in Alfisols with low SOM content, compared to Mollisol with significantly higher SOM (not all of which would be in bonding with clay or physically protected by the inorganic matrix).

The influence of $\mathrm{pH}$ on decomposition of soil humic fraction by UV light is evident from Fig. 6 . Decomposition increased in the order $\mathrm{pH} 6<7.5<9$. Whereas, initially there were only marginal differences in decomposition due to $\mathrm{pH}$ effects, this difference widened with time. Alfisol showed the largest percentage reduction in humic fraction. Mollisol, with the highest humic fraction content showed the smallest percentage loss. Increase in soil $\mathrm{pH}$ would weaken the clay-humus bonding and thereby the protective effect of clay would be reduced (Ahmed et al., 2002). Alkaline $\mathrm{pH}$ also favored free radical formation and consequent oxidative processes.

Solution phase degradation of humic fraction by UV light (Fig. 7) showed much faster rates of decomposition than the humic fraction in soils. The effect of $\mathrm{pH}$ is evident with decomposition following the order $\mathrm{pH} 6<7<8<9$. Every unit increase in $\mathrm{pH}$ caused increased decomposition at more alkaline $\mathrm{pH}$.
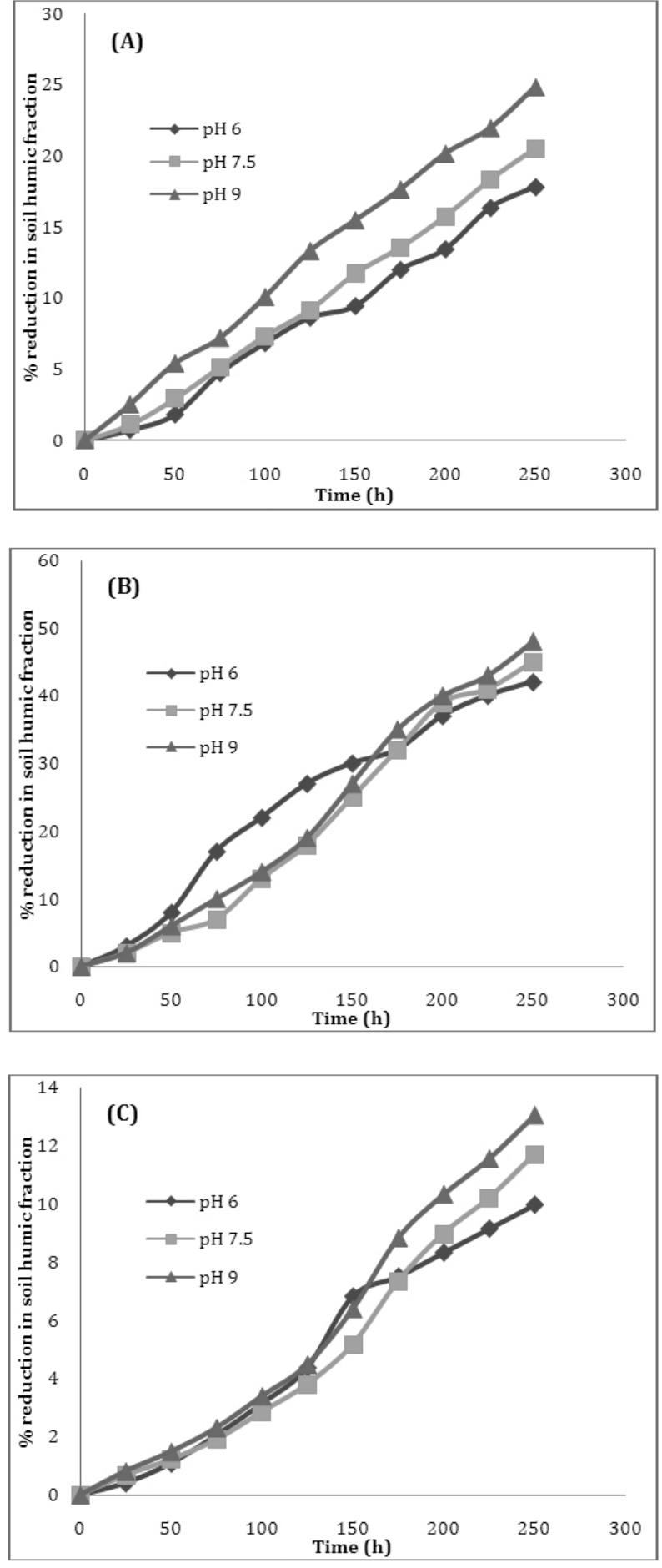

Fig. 6: Percentage reduction in humic fraction in soils of different $\mathrm{pH}$ by UV light (A) Entisol, (B) Alfisol and (C) Mollisol

Such increase is most pronounced from $\mathrm{pH} 8$ to 9 .

The results of these studies clearly establish that sunlight is an important agent of reduction in soil carbon stocks with consequent effect on the global carbon 


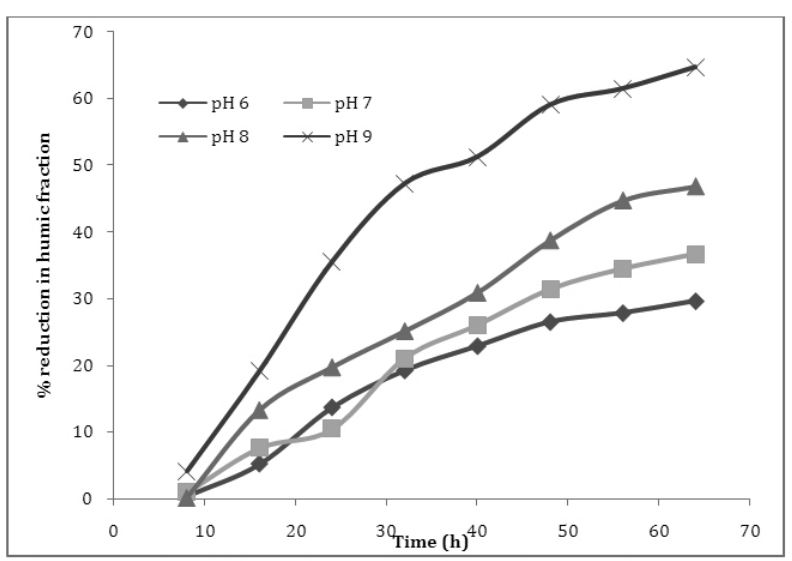

Fig. 7: Effect of $\mathrm{pH}$ on photochemical decomposition of humic fraction in solution by UV light

cycle and climate change. Most resistant of the soil organics, the humic fraction is significantly decomposed even in a short span of 2-3 years. The non-humic fraction is degraded to a greater extent. Deforestation can have a huge impact because of the large reservoirs of non-humic organics that are rapidly oxidized and also because exposure to sunlight causes humic fraction to degrade to smaller molecules

\section{References}

Ahmed N, Varadachari C and Ghosh K (2002) Soil clay-humus complexes. I. Alkali dissolution, TEM and XRD studies Aust J Soil Res 40 691-703

Allard B, Borén H, Pettersson C and Zhang G (1994) Degradation of humic substances by UV irradiation Environ Int 20 97101

Batjes N H (2014) Total carbon and nitrogen in the soils of the world Eur J Soil Sci 65 4-21

Bellamy P H, Loveland P J, Bradley R I, Murray Lark R and Krick G (2005) Carbon losses from all soils across England and Wales 1978-2003 Nature 437 245-248

Bond-Lamberty B and Thomson A (2010) Temperatureassociated increases in the global soil respiration record Nature 464 579-582

Chen Y, Khan S U and Schnitzer M (1978) Ultraviolet irradiation of dilute fulvic acid solutions Soil Sci Soc Am J 41 292-296

Crowther T W and 49 others (2016) Quantifying global soil carbon losses in response to warming Nature 540 104-108

Davidson E A and Janssens I A (2006) Temperature sensitivity of soil carbon decomposition and feedbacks to climate change Nature 440 165-173 which would degrade faster over time. It is estimated that photochemical oxidation following deforestation and consequent exposure to sunlight, could add about $1 \times 10^{4} \mathrm{~kg}$ of $\mathrm{CO}_{2}$ to atmospheric $\mathrm{CO}_{2}$ annually for every hectare of land that is deforested. Our present concepts of global warming assumed that increase in temperatures accelerated biotic processes responsible for $\mathrm{CO}_{2}$ evolution from soils. We suggest that these concepts be expanded to include abiotic factors of sunlight, viz., the photolytic effect of light (particularly the UV component) and the thermal effects of temperature increases on the decomposition reactions. Alkaline soils are particularly susceptible to photodegradation of humic components. In summary, environmentalists and soil scientists need to consider sunlight vis a vis soils as a causative agent of global warming with important factors influencing $\mathrm{C}$ losses being soil $\mathrm{pH}$, initial levels of SOM and its humic and non-humic components and period of leaving the soil fallow.

\section{Acknowledgement}

The authors are grateful to the Indian National Science Academy, New Delhi for support.

Moran A M and Zeep G R (2000) Carbon loss and optical property changes during long term photochemical and biological degradation of estuarian dissolved organic matter Limnol Oceanogr 45 1254-1264

Nelson D W and Sommers L E (1996) Total carbon, organic carbon, and organic matter. In: Methods of Soil Analysis, Part 3 (Sparks, DL, ed.) pp 961-1010, Soil Science Society of America, Madison, Wisc

Saikh H, Varadachari C and Ghosh K (1998) Changes in carbon, nitrogen and phosphorus levels due to deforestation and cultivation: A case study in Simlipal National Park, India Pl Soil 198 137-145

Varadachari C, Mitra S and Ghosh K (2017) Photochemical oxidation of soil organic matter by sunlight Proc Indian Natn Sci Acad 83 223-229

Zeep R G, Braun A M, Hoigne J and Leenheer J A (1987) Photoproduction of hydrated electrons from natural organic solutes in aquatic environment Environ Sci Technol 21 443-450. 